\title{
Pengembangan Modul Pembelajaran Biologi Berbasis Pendekatan Saintifik Untuk Meningkatkan Hasil Belajar Siswa
}

\author{
Muhammad Wahyu Setiyadi ${ }^{1}$, Ismail ${ }^{2}$, Hamsu Abdul Gani ${ }^{3}$ \\ Pendidikan Biologi, Universitas Negeri Makassar \\ Email: wahyusetiyadi074@gmail.com
}

(Received: Juni-2017; Reviewed: Juni-2017; Revised: Juli-2017; Accepted: Juli-2017; Published: Agustus-2017)

C2017 -EST Program Pascasarjana Universitas Negeri Makassar. Ini adalah artikel dengan akses terbuka dibawah licenci CC BY-NC-4.0 (https://creativecommons.org/licenses/by-nc/4.0/ ).

\begin{abstract}
The purpose of this study was to develop a scientific-based learning module on a valid ecological concept, practical and effective to the students of Senior High School. The development procedures of the research employed Thiagarajan Model or 4-D Model which consisted of four stages, namely defining, design, development, and dissemination. The data were collected through learning module validation process, students and teachers' responses questionnaire, learning implementation observation sheet, and learning result test. The data were analyzed by using descriptive analysis. The results of the research reveal that Biology learning module based on scientific approach is valid, practical, and effective. It is stated as valid because Biology learning module based on scientific approach which is developed had met validity criteria with "Valid" category. It is stated as practical because the learning implementation by using Biology learning module based on scientific approach had learning implementation in high category, and students and teachers positive responses on the module. It is stated as effective because it had fulfilled effectiveness namely the students' learning result test had met classical completeness criteria by $84.21 \%$.
\end{abstract}

Keywords: Scientific Approach; Biology Learning Module; Learning Result.

\begin{abstract}
ABSTRAK
Tujuan penelitian ini adalah untuk mengembangkan modul pembelajaran berbasis pendekatan saintifik pada konsep ekologi yang valid, praktis dan efektif bagi siswa Sekolah Menegah Atas. Prosedur pengembangan yang digunakan dalam penelitian adalah model Thiagarajan atau model 4-D terdiri empat tahap yaitu tahap pendefinisian (define), tahap perancangan (design), tahap pengembangan (develop), dan tahap penyebaran (disseminate). Pengumpulan data dilakukan melalui proses validasi modul pembelajaran, angket respon siswa dan guru terhadap modul pembelajaran, lembar observasi keterlaksanaan pembelajaran dan tes hasil belajar. Data uji coba dianalisis dengan menggunakan analisis deskriptif. Hasil penelitian menunjukkan bahwa modul pembelajaran biologi berbasis pendekatan saintifik bersifat valid, praktis, dan efektif. Dikatakan valid karena Modul pembelajaran biologi berbasis pendekatan saintifik yang dikembangkan telah memenuhi kriteria kevalidan dengan kategori "Valid". Modul pembelajaran dikatakan praktis karena keterlaksanaan pembelajaran menggunakan modul pembelajaran biologi ini memiliki keterlaksanaan dengan kategori tinggi, dan siswa dan guru memberikan respon positif terhadap modul pembelajaran. Penggunaan modul pembelajaran berbasis saintifik telah memenuhi kriteria keefektifan karena tes hasil belajar siswa telah memenuhi kriteria ketuntasan klasikal sebesar 84,21\%.
\end{abstract}

Kata kunci: Pedekatan Saintifik, Modul Pembelajaran Biologi, Hasil Belajar. 


\section{PENDAHULUAN}

Berbagai upaya dilakukan pemerintah untuk meningkatkan sumber daya manusia melalui peningkatan kualitas pendidikan. Kurikulum telah mengalami perubahan beberapa tahun terakhir ini. Perubahan kurikulum merupakan salah satu usaha untuk meningkatkan kualitas pendidikan termasuk perkembangan beberapa metode, model, pendekatan, dan strategi pembelajaran. Dalam hal ini pemerintah mengembangkan kurikulum yang telah ada yaitu KBK dan KTSP menjadi Kurikulum 2013.

Kurikulum 2013 merupakan kurikulum baru yang mulai diterapkan pada tahun ajaran 2013/2014. Pelaksanaan kurikulum 2013 dilakukan dengan melatih keterampilan proses yang dicerminkan dalam kegiatan pembelajaran (Kemendikbud, 2013). Keterampilan proses yang diterapkan berupa $5 \mathrm{M}$ (mengamati, menanya, mengumpulkan data, mengasosiasi, dan mengkomunikasikan) yang dikenal sebagai keterampilan proses berupa pendekatan saintifik (Kemendikbud, 2013).

Implementasi kurikulum 2013 memasukan penguatan sikap spiritual, sikap sosial, pengetahuan dan keterampilan dalam proses pembelajaran. Proses pembelajaran merupakan kunci utama dalam kegiatan belajar siswa. Dalam kurikulum 2013, kegiatan pembelajaran perlu menggunakan prinsip: 1) berpusat pada peserta didik, 2) mengembangkan kreativitas peserta didik, 3) menciptakan kondisi menyenangkan dan menantang, 4) bermuatan nilai, etika, estetika, logika, dan kinestetika, dan 5) menyediakan pengalaman belajar yang beragam melalui penerapan berbagai strategi dan metode pembelajaran yang menyenangkan, kontekstual, efektif, efisien, dan bermakna (Permendikbud No. 65 Tahun 2013).

Dalam sistem pendidikan yang menerapkan konsep pembelajaran mandiri, sangat diperlukan bahan-bahan belajar yang dirancang khusus untuk dapat dipelajari oleh peserta didik secara mandiri, karena itu diperlukan para tenaga profesional yang mampu mengembangkan bahan belajar mandiri. Di pihak lain, sumber-sumber referensi tentang pengembangan bahan belajar mandiri sampai saat ini masih sangat terbatas, apalagi sumber pustaka lokal (Purwanto, et al. 2007).

Terkait dengan pengembangan bahan ajar, saat ini pengembangan bahan ajar menjadi kebutuhan yang mendesak. Hal ini merupakan konsekuensi dari perubahan kurikulum lama menjadi kurikulum baru saat ini yakni kurikulum 2013 dengan pendekatan yang dikenal dengan pendekatan saintifik. Menurut Depdiknas (2008) salah satu alasan mengapa bahan ajar harus dikembangkan adalah ketersediaan bahan ajar yang sesuai dengan tuntutan kurikulum, artinya bahan ajar yang dikembangkan harus sesuai dengan kurikulum dengan memperhatikan karakteristik sasaran seperti lingkungan sosial, budaya, geografis, tahapan perkembangan siswa, maupun karakteristik siswa sebagai sasaran. Pengembangan bahan ajar penting dilakukan oleh pendidik agar pembelajaran lebih efektif, efisien, dan tidak melenceng dari kompetensi yang akan dicapainya. Oleh karena itu, bahan ajar sangat penting untuk dikembangkan sebagai upaya untuk meningkatkan kualitas pembelajaran.

Hasil wawancara yang dilakukan terhadap beberapa guru Biologi di beberapa sekolah SMA di kabupaten gowa dalam proses pembelajaran masih banyak menggunakan buku yang sudah ada sebagai sumber belajar bagi siswa dan materi yang disajikan masih banyak bersifat abstrak. Hal ini sebagai salah satu penyebab rendahnya pemahaman dan hasil belajar siswa karena siswa tidak dilibatkan langsung dalam proses pembelajaran dan hanya sekedar menerima apa yang disampaikan oleh guru.

Salah satu cara untuk meningkatkan pemahaman maupun hasil belajar siswa yaitu dengan cara mengembangkan bahan ajar yang baik. Salah satu bahan ajar yang dapat dikembangkan adalah modul. Modul ialah bahan belajar yang dirancang secara sistematis berdasarkan kurikulum tertentu dan dikemas dalam bentuk satuan pembelajaran terkecil dan memungkinkan dipelajari secara mandiri dalam satuan waktu tertentu (Purwanto, et al. 2007). Menurut Direktorat Jenderal Penjaminan Mutu Pendidikan dan Tenaga Kependidikan (2008) modul merupakan bahan ajar cetak yang dirancang untuk dapat dipelajari secara mandiri oleh peserta pembelajaran. Modul disebut juga media untuk belajar mandiri karena di dalamnya telah dilengkapi petunjuk untuk belajar sendiri. Akan tetapi modul-modul yang beredar di pasaran saat ini masih banyak yang belum sesuai dengan kurikulum yang berlaku saat ini yaitu kurikulum 2013. Hal ini mengakibatkan ketersediaan bahan ajar yang sesuai dengan kurikulum 2013 masih terbatas, sehingga bahan ajar yang dalam hal ini adalah modul perlu 
dikembangkan agar sesuai dengan kurikulum yang berlaku.

Modul merupakan paket belajar mandiri yang meliputi serangkaian pengalaman belajar yang direncanakan dan dirancang secara sistematis untuk membantu siswa mencapai tujuan belajar. Tujuan utama pembelajaran dengan modul adalah untuk meningkatkan efisiensi dan efektifitas pembelajaran di sekolah, baik waktu, dana, fasilitas, maupun tenaga guna mencapai tujuan secara optimal (Mulyasa, 2003). Menurut Ditjen PMPTK (2008) modul merupakan sebuah bahan ajar yang disusun secara sistematis dengan menggunakan bahasa yang dapat dengan mudah dipahami oleh siswa serta dapat dipelajari secara mandiri tanpa membutuhkan seorang fasilitator dan modul juga dapat digunakan sesuai dengan kecepatan belajar siswa dengan pengertian tersebut maka modul yang baik memiliki lima karakteristik, yaitu self instruction, self contained, stand alone, adaptive, dan user friendly. Beberapa hasil penelitian menunjukkan bahwa penggunaan modul pada proses pembelajaran dapat meningkatkan hasil pelajaran (Wenno, 2010; Esmiyati et al., 2013; Dewi et al.,2014).

Mengingat pentingnya peranan modul untuk meningkatkan kualitas proses pembelajaran di SMA, maka guru sebagai orang yang paling bertanggung jawab terhadap keberhasilan proses pembelajaran, dituntut untuk dapat memahami pengertian, karakteristik, prinsip, ketentuan dan prosedur pengembangan modul. Pembelajaran dengan menggunakan modul tidak hanya berfokus pada guru tetapi siswa dapat melakukan secara mandiri. Penggunaan modul juga tidak bergantung lagi pada media pembelajaran lain atau tidak harus digunakan bersama-sama dengan media yang lain sehingga lebih efisien. Atas dasar latar belakang tersebut, maka perlu dilaksanakan penelitian dengan judul "Pengembangan Modul Pembelajaran Biologi Berbasis Pendekatan Saintifik Untuk Meningkatkan Hasil Belajar Siswa pada Materi Ekologi”.

\section{METODE PENELITIAN}

Pengembangan modul pembelajaran yang digunakan dalam penelitian ini mengacu pada model 4-D Thiagarajan, Semmel \& Semmel (1974). Model 4-D dipilih berdasarkan pertimbangan bahwa model ini lebih jelas, lengkap, terarah, terstruktur, sistematis dan menuntun pengembang dari awal hingga proses akhir produk yang dihasilkan. Model ini terdiri dari empat tahap yaitu; tahap pembatasan (define), tahap rancangan (design), tahap pengembangan (develop), dan tahap penyebaran (disseminate).

Define (Pendefinisian).Kegiatan pada tahap ini dilakukan untuk menetapkan dan mendefinisikan syarat-syarat pengembangan. Dalam konteks pengembangan bahan ajar yang dalam hal ini adalah modul, tahap pendefinisian dilakukan dengan cara analisis kurikulum, analisis siswa, analisis materi

Design (Perancangan). Pada tahap ini dilakukan perancangan modul pembelajaran berbasis pendekatan saintifik. Kegiatan yang dilakukan pada tahap ini adalah mendesain produk awal modul pembelajaran. Penyusunan desain awal modul pembelajaran melalui tahapan-tahapan sebagai berikut; 1) menetapkan keragka bahan yang akan disusun. 2) penyusunan instrumen penilaian. Modul pembelajaran yang dihasilkan pada tahap ini disebut denganmodul pembelajaran draft 1 .

Develop (Pengembangan). Dalam kegiatan ini dilakukan evaluasi oleh ahli dalam bidangnya. Saran-saran yang diberikan digunakan untuk memperbaiki materi dan rancangan modul pembelajaran yang telah disusun. Dalam pengembangan modul pembelajaran, kegiatan pengembangan (develop) dilakukan dengan langkah-langkah sebagai berikut:

a. Validasi modul pembelajaran oleh ahli/pakar. Hal-hal yang divalidasi meliputi komponen isi dan penyajian, komponen bahasa dan penyajian dan komponen kegrafikan.

b. Revisi model berdasarkan masukan dari para pakar pada saat validasi

c. Uji coba terbatas dalam pembelajaran di kelas, sesuai situasi nyata yang akan dihadapi.

d. Revisi model berdasarkan hasil uji coba Disseminate (Penyebaran). Pengemasan modul pembelajaran dapat dilakukan dengan mencetak modul pembelajaran. Setelah buku dicetak, buku tersebut disebarluaskan supaya dapat diserap (diffusi) atau dipahami orang lain dan digunakan (diadopsi) pada kelas mereka. ${ }^{i}$

Untuk mengukur kevalidan, kepaktisan, dan keefektifan modul pembelajaran, maka disusun dan dikembangkan instrumen penelitian. Instrumen yang digunakan dalam penelitian ini terdiri dari: (1) lembar validasi, (2) angket 
respon guru dan respon siswa, (3) lembar observasi keterlaksanaan pembelajaran dan (4) lembar tes hasil belajar.

Untuk menganalisis data uji coba pada pengembangan modul pembelajaran ini digunakan teknik analisis statistik deskriptif. Data yang dianalisis adalah; data hasil validasi modul pembelajaran, data keterlaksanaan perangkat pembelajaran, data respon siswa, data respon guru, data tes hasil belajar (THB). Analisis data yang diperoleh dikelompokkan menjadi tiga yaitu; (1) analisis data kevalidan modul pembelajaran (2) analisis data kepraktisan (data hasil pengamatan keterlaksanaan pembelajaran, respon siswa, dan respon guru), dan (3) analisis data keefektifan yang di ukur melalui tes hasil belajar (THB).

\section{HASIL DAN PEMBAHASAN}

\section{Hasil}

Berdasarkan tujuan penelitian dengan mengacu pada metodologi, maka telah dilakukan penelitian pengembangan modul pembelajaran berbasis pendekatan saintifik. Penelitian pengembangan ini merujuk pada tiga syarat kualitas yaitu valid, praktis dan efektif serta disusun dan dikembangkan berdasarkan model pengembangan Four D (4-D) (Thiagarajan, et al., 1974) . Penelitian pengembangan ini terdiri dari empat tahapan yaitu; tahap pendefinisian (define), tahap perancangan (design), tahap pengembangan (develop) dan tahap penyebaran (dessiminate). Berikut ini dideskripsikan hasil dari kegiatan yang dilakukan;

Tahap Pendefinisian (Define). Analisis Kurikulum. Hasil analisis kurikulum dalam Permendikbud No. 24 tahun 2016 tentang kompetensi inti dan kompetensi dasar pelajaran pada kurikulum 2013 menunjukan bahwa dalam kurikulum 2013 mengembangkan empat kompetensi inti yakni (KI. I) Kompetensi Inti sikap spiritual, (KI. II) Kompetensi Inti sikap sosial, (KI. III) Kompetensi Inti pengetahuan dan (KI. IV) Kompetensi Inti keterampilan. KD dalam mata pelajaran biologi secara umum di kategorikan menjadi empat arah yakni KD yang mengarah kepada penguatan spiritual, sikap, pengetahuan dan keterampilan. Mengacu pada Permendikbud No. 59 tahun 2014 mengenai karakteristik mata pelajaran dan beban belajar, untuk kelas X minimal dijadwalkan minimal 18 minggu efektif dan beban belajar setiap minggu adalah 42 jam pelajaran. Untuk mata pelajaran biologi setiap minggu efektif memuat 3 jam pelajaran sehingga total jam pelajaran biologi untuk kelas $\mathrm{X}$ adalah 54 jam pelajaran per semester. Dalam kurikulum 2013 materi ekologi berada pada KD 3.10 semester genap, dimana KD 3.10 berbunyi "Menganalisis komponenkomponen ekosistem dan interaksi antar komponen ekosistem".

Analisis Siswa. Siswa merupakan suatu pelaku belajar dengan tingkat dan karakter yang berbeda. Perbedaan karakter tersebut menuntut guru memilih materi dan bahan ajar pembelajaran yang sesuai dengan karakter siswanya. Analisis yang dimaksud dalam penelitian ini adalah analisis perkembangan intelektual dan karakteristik belajar siswa dan tingkat pengetahuan awal siswa.

Inteklektual adalah orang yang menggunakan kecerdasannya untuk bekerja, belajar, membayangkan, menggagas, atau menyoal dan menjawab persoalan tentang berbagai gagasan. Pertumbuhan otak mencapai kesempurnaan pada usia 12-20 tahun secara fungsional. Pada usia remaja mental anak telah dapat berpikir logis tentang berbagai gagasan abstrak. Dengan kata lain, berpikir operasi formal lebih bersifat hipotesis dan abstrak serta sistematis dan ilmiah dalam memecahkan masalah daripada berpikir konkret. Mar'at (2005) dalam Madeamin (2016) mengatakan bahwa tahap ini anak sudah berpikir secara abstrak dan hipotesis serta mampu memikirkan sesuatu yang akan terjadi. Kemampuan kognitif terus berkembang selama masa SMA. Akan tetapi, tidak semua perubahan kognitif pada masa SMA tersebut mengarah pada peningkatan potensi. Kadang-kadang beberapa kemampuan kognitif mengalami kemerosotan seiring dengan pertambahan usia.

Secara umum, karakteristik siswa kelas X SMA Negeri 1 Bajeng Barat dapat dilihat dari segi perkembangan kogitif. Pada aspek perkembangan kognitif, tampak siswa kelas $\mathrm{X}$ SMA N 1 Bajeng Barat kurang mampu memahami materi yang disebabkan oleh cara belajar mereka yang terkesan menghafal konsep dan cara guru menyajikan materi kepada siswa untuk melakukan proses berpikir sehingga siswa hanya sekedar menerima pengetahuan atau pun teori yang ada dari guru. Oleh karena itu, agar dapat melakukan proses berpikir dalam memahami konsep-konsep yang dipelajarinya sesuai dengan tingkat perkembangan kognitifnya, maka dalam penelitian ini 
digunakan pendekatan saintifik dengan menggunakan bahan ajar modul.

Analisis materi. Analisis materi dilakukan untuk menentukan rancangan materi pembelajaran yang akan di susun. Analisis materi dilakukan dengan cara mengidentifikasi materi utama yang perlu diajarkan, mengumpulkan dan memilih materi yang relevan, dan menyusunnya kembali secara sistematis. Materi disusun untuk memenuhi tuntutan dalam indikator dan tujuan pembelajaran berdasarkan KI dan KD dalam kurikulum 2013. Konsep ekologi dalam kurikulum 2013 di ajarkan pada semester genap dan menempati kompetensi dasar 3.10. dimana KD 3.10 berbunyi "Menganalisis komponenkomponen ekosistem dan interaksi antar komponen ekosistem". Sedangkan KD 4.10 berbunyi "Menyajikan karya yang menunjukkan interaksi antar komponen ekosistem (jaringjaring makanan, siklus Biogeokimia)". Konsepkonsep yang relevan dengan KD 3.10 dan $\mathrm{KD}$ 4.10 yaitu; (1) konsep lingkungan yang terdiri dari komponen biotik dan komponen abiotik, (2) peranan komponen ekosistem, (3) interaksi yang meliputi pola interaksi antara komponen biotik dengan biotik dan pola interaksi antara komponen biotik dengan abiotik (saling ketergantungan antar komponen dalam ekosistem), (4) siklus biogeokimia.

Desain Awal Modul (Design). Pada tahap ini dilakukan perancangan modul pembelajaran berbasis pendekatan saintifik. Kegiatan yang dilakukan pada tahap ini adalah mendesain produk awal modul pembelajaran. Penyusunan desain awal modul pembelajaran melalui tahapan-tahapan sebagai berikut; 1) menetapkan kerangka bahan yang akan disusun. 2) penyusunan instrumen penilaian. Selain menetapkan penyusunan kedua komponen tersebut pada tahap desain awal modul, juga ditetapkan tujuan akhir yang berisi kemampuan yang harus dikuasai oleh siswa, garis-garis besar atau outline substansi atau materi untuk mencapai tujuan yang telah ditetapkan, yaitu komponen-komponen kompetensi dasar (KD), dan tugas tugas yang akan di selesaikan oleh siswa.

Pengembangan (Develop). Tahap ini bertujuan untuk menghasilkan modul pembelajaran yang layak digunakan dalam kegiatan pembelajaran di kelas. Rancangan awal modul pembelajaran (draft I) diberikan kepada ahli/pakar untuk dinilai, yang selanjutnya perangkat tersebut direvisi dengan memperhatikan saran/masukan dari ahli/pakar.

Penilaian modul pembelajaran ini dilakukan pada aspek kelayakan isi dan penyajian, aspek bahasa dan penyajian, dan aspek kegrafikan. Berdasarkan hasil analisis dapat diketahui rerata ke tiga komponen penilaian yaitu komponen kelayakan isi dan penyajian dengan rata-rata ( $\mathrm{Va}$ ) 4,03, berdasarkan ketentuan nilai ini dikatakan valid $(3,5 \leq \mathrm{Va}<4,5)$. Komponen kelayakan bahasa dan penyajian dengan rata-rata (Va) 4,32, berdasarkan ketentuan nilai ini dikatakan valid $(3,5 \leq \mathrm{Va}<4,5)$. Komponen kegrafikan dengan rata-rata (Va) 4,14, berdasarkan ketentuan nilai ini dikatakan valid $(3,5 \leq \mathrm{Va}<4,5)$. Dari besaran angka yang didapat rerata total sebesar 4.16 $(3,5 \leq \mathrm{Va}<4,5)$ sehingga dapat disimpulkan bahwa modul pembelajaran biologi pada konsep ekologi dinilai valid dan layak untuk digunakan.

Berdasarkan hasil validasi dan saran/masukan dari ahli dilakukan perbaikan/revisi pada modul pembelajaran (draft I), sehingga dihasilkan modul pembelajaran hasil revisi (draft II). Selanjutnya, modul pembelajaran hasil revisi (darft II) diujicobakan dalam kegiatan pembelajaran di kelas.

Uji coba pemakaian modul pembelajaran biologi berbasis pembelajaran saintifik dilakukan kepada 38 siswa kelas $\mathrm{X}$ MIA 3 SMA Negeri 1 Bajeng Barat. Angket respon siswa diisi oleh siswa dan guru setelah kegiatan pembelajaran selesai. Siswa mengerjakan soal tes hasil belajar setelah dua kali tatap muka $(6 \times 45$ menit $)$ di kelas. Keseluruhan hasil uji coba dianalisis dan hasilnya menjadi dasar perbaikan modul pembelajaran untuk draft akhir.

Analisis data kepraktisan modul pembelajaran. Indikator yang digunakan untuk menentukan kepraktisan modul pembelajaran yaitu; (1) keterlaksanaan pembelajaran, (2) respon siswa dan guru. Hasil analisis data kepraktisan modul pembelajaran setelah ujicoba dilaksanakan adalah:

Keterlaksanaan pembelajaran. Hasil analisis keterlaksanaan pembelajaran untuk setiap aspek pengamatan adalah, Nilai rata-rata validitas $(\bar{X})$ untuk aspek sintaks pembelajaran adalah $\bar{X}=3,8$. Berdasarkan kriteria keterlaksanaan , nilai ini termasuk dalam kategori "terlaksana cukup baik/sedang" $(3 \leq \bar{X}$ $\leq 4)$, Nilai reliabilitas untuk aspek ini adalah PA $=75 \%$. Nilai ini termasuk dalam kategori "Reliabel" (PA $\geq 75 \%)$. Nilai rata-rata validitas 
$(\bar{X})$ untuk aspek interaksi sosial adalah $\bar{X}=4$. Berdasarkan kriteria keterlaksanaan, nilai ini termasuk dalam kategori "terlaksana baik atau tinggi" $(4 \leq \bar{X} \leq 5)$. Nilai reliabilitas untuk aspek ini adalah $\mathrm{PA}=100 \%$. Nilai ini termasuk dalam kategori "Reliabel" (PA $\geq 75 \%)$. Nilai rata-rata validitas $(\bar{X})$ untuk aspek prinsip reaksi adalah $\bar{X}$ $=4$. Berdasarkan kriteria keterlaksanaan, nilai ini termasuk dalam kategori "terlaksana baik atau tinggi" $(4 \leq \bar{X} \leq 5)$. Nilai reliabilitas untuk aspek ini adalah PA $=80 \%$. Nilai ini termasuk dalam kategori "Reliabel" (PA $\geq 75 \%$ ). Nilai rata-rata validitas $(\bar{X})$ untuk aspek pendukug adalah $\bar{X}=4,63$. Berdasarkan kriteria keterlaksanaan, nilai ini termasuk dalam kategori "terlaksana baik atau tinggi" $(4 \leq \bar{X} \leq$ 5). Nilai reliabilitas untuk aspek ini adalah $\mathrm{PA}=$ $75 \%$. Nilai ini termasuk dalam kategoori "Reliabel" ( $\mathrm{PA} \geq 75 \%)$. Nilai rata-rata validitas $(\bar{X})$ untuk keseluruhan aspek adalah $\bar{X}=4,13$. Berdasarkan kriteria keterlaksanaan, nilai ini termasuk dalam kategori "terlaksana baik atau tinggi" $(4 \leq \bar{X} \leq 5)$. Nilai reliabilitas untuk aspek ini adalah PA $=82,5 \%$. Nilai ini termasuk dalam kategoori "Reliabel" (PA $\geq 75 \%$ ).

Hasil data respon siswa terhadap uji coba penggunaan modul pembelajaran biologi berbasis pembelajaran saintifik pada konsep ekologi dalam proses pembelajaran biologi didapatkan hasil yang baik dengan total persentase lebih dari 50\% siswa memberikan respon positif terhadap modul pembelajaran biologi berbasis pendekatan saintifik pada konsep ekologi yaitu 84,23 \%. Hal ini menunjukan bahwa siswa memiliki respon yang positif. Kemudian hasil data respon dua orang guru terhadap modul pembelajaran biologi berbasis pendekatan saintifik pada konsep ekologi didapatkan hasil yang baik dengan ratarata persentase kategori kuat dan sangat kuat lebih dari $50 \%$ yaitu $88,7 \%$. Hal ini menunjukan bahwa guru memiliki respon yang positif terhadap modul pembelajaran biologi berbasis pendekatan saintifik pada konsep ekologi.

Analisis data keefektifan modul pembelajaran. Berdasarkan kriteria ketuntasan minimal di sekolah SMA Negeri 1 Bajeng Barat, seorang siswa dikatakan berhasil dalam belajar jika memperoleh nilai minimal 75. Pembelajaran dikatakan berhasil secara klasikal jika minimal $80 \%$ siswa mencapai skor minimal 75.dari hasil uji coba, terdapat 32 siswa yang memenuhi kriteria ketuntasan minimal (KKM) dengan persentase klasikal $84,21 \%$, sedangkan terdapat 6 orang siswa yang belum tuntas dengan persentase $15,8 \%$. Dari hasil tersebut karena persentase secara klasikal $(84,2 \%)$ lebih besar dari pada ketentuan ketuntasan klasikal $(80 \%)$ dapat disimpulkan bahwa kelas uji coba yang menggunakan modul pembelajaran sebagai bahan ajar tuntas secara klasikal.

\section{Pembahasan}

Kevalidan perangkat pembelajaran. Berdasarkan penilaian ahli dan pakar terhadap modul diperoleh nilai rata-rata keseluruhan 4,16 dengan kategori "valid", ini menunjukkan bahwa modul pembelajaran berbasis pendekatan saintifik yang dikembangkan memenuhi kriteria kevalidan. Meskipun begitu, terdapat beberapa saran dan masukan dari ahli untuk dilakukan revisi kecil agar modul pembelajaran yang dikembangkan mejadi lebih baik.

Modul pembelajaran biologi berbasis pendekatan saintifik yang dikembangkan dapat dikatakan valid jika semua ahli yang memvalidasi menyatakan valid. Pendapat ini didukung oleh hasil penelitian Sawitri, et al. (2014) yang menyatakan bahwa modul pembelajaran yang berkualitas dan layak digunakan jika telah memenuhi standar kevalidan yang dinilai oleh ahli dan pakar. Selain itu Hala, et al. (2015) menyatakan validasi telah memenuhi kriteria kevalidan jika dalam hal ini instrumen yang dikembangkan telah didasari pada kajian rasional teoritik yang kuat serta memiliki konsistensi secara internal.

Kepraktisan Modul Pembelajaran. Berdasarkan kriteria keterlaksanaan pembelajaran menggunakan modul berbasis pendekatan saintifik diperloleh nilai rata-rata total 4,13 dan persentase of agreement sebesar $82,5 \%$, yang berarti keterlaksanaan pembelajaran menggunakan modul pembelajaran berbasis saintifik terlaksanan dengan baik atau tinggi dan siswa terlibat aktif dalam pembelajaran. Selain itu, tampak bahwa modul yang dikembangkan mampu mengarahkan siswa untuk terlibat aktif dan berinteraksi dengan temannya serta berinteraksi dengan guru untuk menyampaikan dan memecahkan permasalahan atau pertanyaan yang berkaitan dengan isi materi modul pembelajaran. Jadi modul pembelajaran yang dikembangkan telah memenuhi syarat kepraktisan. Oleh karena itu modul pembelajaran yang dikembangkan praktis untuk digunakan dalam pembelajaran. Hal ini didukung oleh Ismail (2013) yang menyatakan bahwa keterlaksanaan pembelajaran yang baik 
adalah jika derajat keterlaksanaan pembelajaran yang dicapai tersebut minimal berkategori tinggi atau baik.

$$
\text { Respon siswa terhadap kegiatan }
$$
pembelajaran menggunakan modul pembelajaran menunjukkan kategori respon positif, dimana dari total 20 pertanyaan terdapat 14 pertanyaan dengan respon sangat kuat dan 4 pernyataan dengan respon kuat. Rata-rata dari setiap pernyataan adalah $84,23 \%$ sehingga respon siswa terhadap modul pembelajaran dapat dikatakan positif. Selain itu, respon guru didapatkan rata-rata persentase kategori kuat dan sangat kuat sebesar $88,7 \%$ sehingga respon guru terhadap modul pembelajaran dapat dikatakan positif.

Respon positif siswa terhadap modul pembelajaran disebabkan karena siswa dilibatkan secara langsung dalam proses pembelajaran melalui kegiatan 5 M (mengamati, menanya, ngumpulkan informasi, mengasosiasi, dan mengkomunikasikan), sedangkan selama ini siswa cenderung pasif dan sekedar menerima informasi dari guru sehingga siswa kaya akan teori tetapi lemah dalam pengaplikasiannya.

Selain itu respon positif siswa terhadap modul pembelajaran juga disebabkan karena terdapat petunjuk penggunaan modul pembelajaran sehingga mereka mampu melakukan pembelajaran secara mandiri, siswa memahami langkah kerja yang terdapat dalam lembar kegiatan siswa karena didukung oleh bahasa dan petunjuk yang mampu menuntun mereka untuk melakukan kegiatan, terdapat gambar atau ilustrasi yang dapat diamati untuk memudahkan siswa dalam memahami pelajaran, terdapat informasi pendukung yang dapat menambah pengetahuan mereka, dan terdapat soal-soal latihan untuk meningkatkan pengetahuan dan soal-soal untuk melakukan asesmen secara mandiri.

Dalam pengembangan modul ini, selain berpedoman pada pedoman penulisan modul Departemen Pendidikan Nasional (2008) tentang pengembangan bahan ajar, pengembangan modul ini juga memperhatikan karakteristik modul yang terdiri atas lima karakteristik modul, yaitu self instruction, self contained, stand alone, adaptive, dan user friendly (Ditjen PMPTK, 2008; Rahdiyanta, 2012; Sawitri, et al.,2014), sehingga dengan adanya karakteristik ini dalam modul dapat menuntun dan membantu siswa dalam proses pembelajaran. Sebagai contoh telah terdapat lima kesesuaian modul terhadap karakteristik modul yang terdapat dalam modul pembelajaran biologi berbasis pendekatan saintifik pada konsep ekologi, yaitu self instruction, terdapat beberapa kalimat perintah yang mudah untuk dipahami, terdapat soal-soal latihan, tugas dan sejenisnya yang memungkinkan untuk mengukur penguasaan peserta didik, terdapat rangkuman materi pembelajaran dan memuat materi pembelajaran yang dikemas dalam unit-unit yang kecil, sehingga memudahkan dipelajari secara tuntas. Self contained, pada modul ekologi berbasis pendekatan saintifik yang dikembangkan terdapat materi pokok, yaitu ekologi yang telah dibagi menjadi dua topik utama, yaitu 1) Komponen ekosistem, interaksi antar komponen dalam ekosistem, dan aliran energi, dan 2) Siklus biogeokimia untuk mencapai kompetensi inti dan kompetensi dasar sesuai dengan Kurikulum 2013. Stand alone, modul yang dikembangkan telah dapat berdiri sendiri ditunjukkan salah satunya terdapat pada lembar kerja siswa mulai dari mengamati hingga mengkomunikasikan siswa dapat melaksanakan seluruh kegiatan pembelajaran 5M tanpa menggunakan bahan ajar/media lain pada modul. Adaptive, pada bagian ini modul memiliki daya adaptasi terhadap perkembangan ilmu dan teknologi. Terakhir, yaitu User friendly pada modul ekologi berbasis pendekatan saintifik yang dikembangkan telah dapat bersahabat dengan pengguna (siswa) karena pada modul terdapat instruksi dan paparan informasi yang bersifat membantu dan bersahabat dengan pemakainya.

Keefektifan Modul Pembelajaran. Tahapan terakhir untuk mengetahui efektivitas penggunaan modul pembelajaran biologi berbasis pendekatan saintifik adalah menerapkan rencana pembelajaran dan modul yang telah disusun kedalam uji coba pemakaian dalam proses pembelajaran. Proses pembelajaran pada pendekatan saintifik adalah memberikan peluang dan kesempatan kepada peserta didik untuk mencari tahu dan menumbuhkan rasa ingin tahunya melalui kegiatan 5 M (mengamati, menanya, mengumpulkan informasi, mengasosiasi, dan menginformasikan (Permendikbud No. 103 Tahun 2014).

Keefektifan modul pembelajaran biologi ini dapat diketahui dengan melihat hasil belajar peserta didik. Berdasarkan hasil belajar peserta didik kelas $\mathrm{X}$ diperoleh 32 siswa mencapai kriteria ketuntasan minimal (75) sedangkan 6 
siswa lainnya belum mencapaik KKM. Alasan 6 siswa tidak mencapai KKM dikarenakan. Peserta didik tersebut tidak konsentrasi penuh dalam mengikuti proses pembelajaran serta adanya faktor-faktor lainnya yang menghambatnya dalam menerima atau melakukan aktifitas dalam modul pembelajaran. Hal ini menunjuk pada 84,21 \% siswa telah mengalami ketuntasan hasil belajar secara klasikal. Suatu modul pembelajaran dinyatakan efektif apabila $80 \%$ siswa yang mengikuti pembelajaran mampu mencapai nilai acuan yang telah ditetapkan sebelumnya (Hobri. 2010).

Berdasarkan hal tersebut, kelas uji coba setelah diberikan perlakuan dengan pemberian bahan ajar modul pembelajaran berbasis saintifik tuntas secara klasikal. Jadi, pembelajaran dengan menggunakan modul pembelajaran berbasis pendekatan saintifik pada konsep ekologi yang telah dikembangkan dapat meningkatkan kemampuan kognitif siswa. Hal ini terjadi karena di dalam modul terdapat kegiatan-kegiatan yang dapat mendukung siswa dalam proses pembelajaran dengan pendekatan berbasis saintifik, siswa terlibat aktif dalam melakukan percobaan atau menganalisis guna mengumpulkan data atau informasi serta mendiskusikan hasil pengamatan atau analisisnya untuk menarik kesimpulan, sehingga dalam pembelajaran terjadi proses konstruksi pengetahuan pada diri siswa.

Alasan kuat mengapa modul pembelajaran biologi berbasis pendekatan saintifik efektif untuk meningkatkan hasil belajar siswa adalah melihat beberapa keunggulan pembelajaran dengan sistem modul dikemukakan sebagai berikut: 1) berfokus pada kemampuan individual peserta didik, karena pada hakekatnya mereka memiliki kemampuan untuk bekerja sendiri dan lebih bertanggung jawab atas tindakan-tindakannya, 2) adanya kontrol terhadap hasil belajar melalui penggunaan standar kompetensi dalam setiap modul yang harus dicapai oleh peserta didik, 3) kesesuaian kurikulum ditunjukkan dengan adanya tujuan dan cara pencapaiannya, sehingga peserta didik dapat mengetahui keterkaitan antara pembelajaran dan hasil yang akan diperolehnya. Hal ini sejalan dengan yang di ungkapkan Rahdiyanta (2012) keunggulan modul dalam proses pembelajaran adalah modul mampu mengatasi keterbatasan waktu, ruang, dan daya indera, baik siswa atau peserta diklat maupun guru/instruktur, meningkatkan motivasi dan gairah belajar bagi siswa atau peserta diklat, dan memungkinkan siswa atau peserta diklat belajar mandiri sesuai kemampuan dan minatnya sehingga modul dapat menggantikan peran guru dalam proses pembelajaran.

Selain keunggulan yang dimiliki modul, bila dikaitkan dengan pendekatan saintifik, pendekatan saintifik pada kurikulum 2013 dapat melatih peserta didik untuk lebih mandiri, kreatif dan inovatif. Melaui konsep 5M, peserta didik dididik untuk dapat mencari informasi, menemukan, menyampaikan pendapat didepan kelas, mengevaluasi dan menarik kesimpulan secara aktif dan mandiri, sehingga peserta didik dapat mengkonstruk pengetahuannya sendiri.

Pembelajaran dengan modul membuat siswa aktif, berfikir kreatif dan membantu siswa menemukan konsep. Hal ini sesuai dengan teori belajar Bruner yang menyatakan bahwa proses belajar akan berjalan dengan baik jika guru memberikan kesempatan kepada siswa untuk menemukan konsep, teori, ataupun pemahaman melalui contoh-contoh yang dijumpainya (Budiningsih, 2012). Hasil yang diperoleh sejalan dengan hasil penelitian Novianty, et al. (2013), yaitu modul yang disusun berdasarkan pendekatan saintifik yang dikenal dengan $5 \mathrm{M}$ efektif meningkatkan hasil belajar siswa dan persepsi siswa terhadap isi modul serta pembelajaran dengan bantuan modul sangat positif.

Pada tahap mengamati, siswa difasilitasi untuk melakukan pengamatan dengan kegiatan membaca, menyimak, melihat apa yang disajikan pada kegiatan pendahuluan modul. Pada tahap ini siswa menghubungkan pengetahuan awal yang dimiliki dengan fenomena yang sekarang dihadapi. Kegiatan mengamati sangat bermanfaat bagi penumbuhan rasa ingin tahu peserta didik, sehingga proses pembelajaran memiliki kebermaknaan yang tinggi (Majid \& Rochman, 2014). Kegiatan mengamati juga dapat melatih kesungguhan dan ketelitian peserta didik (Hosnan. 2014). Hal ini sesuai dengan pernyataan Piaget yang menyatakan bahwa ilmu pengetahuan dibangun dalam pikiran seorang anak dengan kegiatan asimilasi, akomodasi dan ekuilibrasi. Asimilasi ialah pemaduan data baru dengan stuktur kognitif yang ada. Akomodasi ialah penyesuaian struktur kognitif terhadap situasi baru, dan equilibrasi ialah penyesuaian kembali yang terus dilakukan antara asimilasi dan akomodasi (Budiningsih, 2012).

Pada tahap menanya, siswa difasilitasi untuk mengidentifikasi dan menuliskan hal-hal 
yang tidak dipahami pada kegiatan mengamati dalam bentuk pertanyaan-pertanyaan sederhana pada modul. Hal ini sesuai dengan pandangan dasar dalam kurikulum 2013 bahwa pembelajaran harus berkenaan dengan kesempatan yang diberikan kepada peserta didik untuk mengkonstruksi pengetahuan dalam proses kognitifnya (Hosnan. 2014). Adapun kompetensi yang diharapkan dalam kegiatan ini adalah mengembangkan kreativitas, rasa ingin tahu, kemampuan merumuskan pertanyaan untuk membentuk pikiran kritis yang perlu untuk hidup cerdas dan belajar sepanjang hayat (Permendikbud Nomor 81A Tahun 2013).

Pada tahap mengumpulkan informasi, pada modul ini disediakan lembar kegiatan siswa yang berisi petunjuk praktikum dan pertanyaan-pertanyaan yang menuntun siswa untuk dapat membangun konsep berdasarkan rumusan masalah yang diajukan pada setiap kegiatan/pertemuannya. . Pada tahap ini diharapkan siswa mengembangkan sikap teliti, jujur, sopan, menghargai pendapat orang lain, kemampuan berkomunikasi, menerapkan kemampuan mengumpulkan informasi melalui berbagai cara yang dipelajari, mengembangkan kebiasaan belajar dan belajar sepanjang hayat (Permendikbud Nomor 81A Tahun 2013). Kegiatan ini membuat proses pembelajaran menjadi efektif, karena semua siswa di dalam kelompoknya melakukan aktivitas sesuai dengan penuntun dalam modul pembelajaran, diskusi dan berintekrasi dengan guru dan temannya dalam menyelesaikan lembar kegiatan tersebut. Menurut teori asosiasi, proses pembelajaran akan berhasil secara efektif jika terjadi interaksi langsung antara pendidik dengan peserta didik (Hosnan. 2014). Jika siswa tidak mencapai KKM, siswa dapat mengulang kembali mengerjakan lembar kegiatan tersebut sampai siswa tersebut merasa puas dengan nilai yang diperolehnya.

Pada tahap mengasosisasi siswa diarahkan mengolah informasi-informasi yang didapatkan pada tahap sebelumnya yaitu tahap mengumpulkan informasi sampai kepada proses penarikan kesimpulan secara mandiri ataupun bersama dengan teman-temannya. Dalam Permendikbud Nomor 81A Tahun 2013 aktivitas ini juga diistilahkan sebagai kegiatan menalar, yaitu proses berfikir yang logis dan sistematis atas fakta-kata empiris yang dapat diobservasi untuk memperoleh simpulan berupa pengetahuan sehingga pengalaman-pengalaman yang sudah tersimpan di memori otak berelasi dan berinteraksi dengan pengalaman sebelumnya. Setelah menemukan keterkaitan antar informasi dan menemukan berbagai pola dari keterkaitan tersebut, selanjutnya secara bersama-sama dalam satu kesatuan kelompok, atau secara individual membuat kesimpulan.

Pada tahap mengkomunikasikan, siswa menyampaikan hasil pengamatan atau kesimpulan secara tulisan pada lembaran yang telah disediakan pada modul atau secara lisan melalui persentasi di kelas. Melalui kegiatan mengkomunikasikan siswa mengembangkan sifat jujur, teliti, toleransi, kemampuan berfikir sistematis, mengungkapkan pendapat dengan singkat dan jelas dan mengembangkan kemampuan berbahasa yang baik dan benar (Permendikbud Nomor 81A Tahun 2013).Pendekatan saintifik mempermudah siswa untuk memahami materi yang disampaikan dan lebih membuat siswa untuk bertindak aktif (Purwaningsih, et al., 2014).

Selain itu adanya tes formatif dan kunci jawaban yang ada pada modul bertujuan untuk membantu siswa untuk menguji kemampuannya sendiri terhadap materi yang telah dipelajarinya. Menurut Rahdiyanta (2012) tes ini sebagai bahan pengecekan bagi peserta didik dan guru untuk mengetahui sejauh mana penguasaan hasil belajar yang telah dicapai, sebagai dasar untuk melaksanakan kegiatan berikut. Dengan demikian siswa bisa mendapat feedback secepat mungkin dan dapat belajar sendiri atau dengan bimbingan guru seminimal mungkin yang akhirnya akan berpengaruh terhadap peningkatan hasil belajar siswa.

\section{SIMPULAN DAN SARAN}

Modul pembelajaran biologi pada konsep ekosistem dikembangkan menggunakan model 4-D yang terdiri dari empat tahap yaitu define, design, develop dan dessiminate. Modul pembelajaran biologi berbasis pendekatan saintifik memiliki nilai validitas $=4,16$ dengan kategori valid, dengan begitu modul pembelajaran biologi pada konsep ekologi memenuhi kriteria kevalidan. Keterlaksanaan pembelajaran diperloleh nilai rata-rata 4,13 dan persentase of agreement sebesar 82,5\%, yang berarti keterlaksanaan pembelajaran menggunakan modul pembelajaran berbasis saintifik terlaksana dengan baik dan siswa terlibat aktif dalam pembelajaran. Perolehan respon siswa terhap modul pembelajaran dengan persentase rata-rata kategori kuat dan kuat 
adalah $84,23 \%$ dan respon guru sebesar $88,7 \%$ sehingga dapat disimpulkan respon siswa dan guru adalah positif, dengan begitu modul pembelajaran biologi berbasis pendekatan saintifik memenuhi kriteria kepraktisan. Modul pembelajaran berbasis pendekatan saintifik pada konsep ekosistem memenuhi kriteria keefektifan, hal ini berdasarkan pada pencapaian ketuntasan belajar secara klasikal dengan persentase ketuntasan $84,2 \%$.

Disarankan kepada peneliti selanjutnya untuk melakukan ujicoba dalam skala luas agar dihasilkan modul pembelajaran yang lebih baik. Disarankan kepada peneliti lain untuk dapat mengambangkan modul pembelajaran berbasis pendekatan saintifik pada konsep yang lain.

\section{DAFTAR RUJUKAN}

Budiningsih, A. (2012). Belajar dan Pembelajaran. Jakarta: PT Rineka Cipta.

Depdiknas. (2008a). Pengembangan Bahan Ajar. Jakarta: Depdiknas.

Dewi, A. P., Sarwanto., \& Prayitno, B. A. (2014). Pengembangan Modul IpaTerpadu Untuk Smp/Mts Berbasis Eksperimen Pada Tema Fotosintesis Untuk Memberdayakan Keterampilan Proses Sains. Jurnal Inkuiri, Vol 3, No. III, (hal 30-40).

Ditjen PMPTK. (2008). Penulisan Modul. Jakarta: Ditjen PMPTK Depdiknas.

Esmiyati., Haryati, S., \& Purwantoyo, E. (2013). Pengembangan Modul IPA Terpadu Bervisi SETS (Science, Environtment, Technology, and Society) Pada Tema Ekosistem. Unnes Science Education 2(1): 180-187.

Hala, Y., Saenab, S., Kasim. S. (2015). Pengembangan Perangkat Pembelajaran Biologi Berbasis Pendekatan Saintifik Pada Konsep Ekosistem Bagi Siswa Sekolah Menengah Pertama. Journal of Educational Science and Tecnology, Volume 1 Nomor 3: 85-96.

Hobri. (2010). Metodologi Penelitian Pengembangan (Aplikasi Pada Penelitian Pendidikan Matematika). Jember: Pena Salsabila.
Hosnan. (2014). Implementasi Saintifik dan Kontekstual dalam Pembelajaran Abad 21. Bogor: Ghalia Indonesia.

Ismail. (2013). Pengembangan Model Pembelajaran IPA Terintegrasi Nilai Karakter di Sekolah Dasar. Disertasi, Makassar. PPS-UNM.

Kemendikbud. (2013). Implementasi Kurikulum 2013. Jakarta: Kementerian Pendidikan dan Kebudayaan.

Lampiran Permendikbud No 65. (2013). Standar Proses Pendidikan Dasar dan Menengah. (online) http://vokasi.unud.ac.id/wpcontent/uploads/2014/08/03-b-salinanlampiran-permendikbud-no-65-th-2013ttg-standar-proses.pdf . diakses 6 oktober 2016.

Madeamin, S. (2016). The development of indosesian language learning materials based on local excellence of the first grade students at SMA Negeri 3 Palopo. Unpublished dissertation. Makassar: PPs Universitas Negeri Makassar

Majid, A \& Rochman, C. (2014). Pendekatan Ilmiah dalam Implementasi Kurikulum 2013. Bandung: PT Remaja Rosdakarya.

Mulyasa, E. (2003). Konsep, Karakteristik, Implementasi, dan Inovasi Kurikulum Berbasis Kompetensi. Bandung: PT Remaja Rosdakarya.

Novianty, I., Sulistina, O., \& Zakia, N. (2013). Efektivitas Penerapan Modul Materi Analisis Elektrokimia Berbasis Inkuiri Terbimbing Terhadap Hasil Belajar Dan Persepsi Siswa Kelas Xi Semester 1 Kompetensi Keahlian Kimia Analisis Smkn 7 Malang: Universitas Negeri Malang.

Permendikbud Nomor 24 Tahun 2016 Tentang Kompetensi Inti Dan Kompetensi Dasar Pelajaran Pada Kurikulum 2013 Pada Pendidikan Dasar Dan Pendidikan Menengah. Jakarta: Kementrain Pendidikan dan Kebudayaan Republik Indonesia.

Peraturan Menteri Pendidikan Dan Kebudayaan Republik Indonesia Nomor 59 Tahun 
2014 Tentang Kurikulum 2013 Sekolah Menengah Atas/Madrasah Aliyah. Jakarta: Kementrain Pendidikan dan Kebudayaan Republik Indonesia.

Permendikbud Nomor 81A Tahun (2013) lampiran IV tentang Implementasi Kurikulum Pedoman Umum Pembelajaran. Jakarta: (online) http://luk.staff.ugm.ac.id/atur/bsnp/Perm endikbud81A-

2013ImplementasiK13Lengkap.pdf. di akses 5 oktober 2016.

Permendikbud Nomor 103 Tahun 2014 tentang Pembelajaran Pada Pendidikan Dasar Dan Pendidikan Menengah. Jakarta : Kementrian Pendidikan dan Kebudayaan Republik Indonesia.

Purwaningsih, E., Fadiawati, N., \& Kadaritna, N. (2014). Penggunaan Pendekatan Scientific pada Pembelajaran Kesetimbangan Kimia dalam Meningkatkan Keterampilan Elaborasi. Jurnal Pendidikan dan Pembelajaran Kimia. Vol. 3 No. 1 hal: 1-14.

Purwanto., Rahadi, A., \& Lasmono, S. (2007). Pengembangan Modul. Jakarta: Pusat Teknologi Informasi dan Komunikasi Pendidikan (PUSTEKKOM) Depdiknas. Rahdiyanta, D. (2012). Teknik Penyusunan Modul. Artikel. (Online) http://staff.uny.ac.id/sites/default/files/p enelitian/dr-dwi-rahdiyanta-mpd/20teknik-penyusunan-modul.pdf. diakses 10 oktober 2016.

Sawitri, D. W., Ambarwati, R., \& Wisanti. (2014). Pengembangan Modul Keanekaragaman Hayati Berbasis Pendekatan Saintifik Untuk Siswa Kelas $\mathrm{X}$ Sma. BioEdu Berkala Ilmiah Pendidikan Biologi, Vol.3 No.3.

Thiagarajan, S., Semmel, DS. Semmel, M. (1974). Instructional Development for Training Teachers of Exceptional Childern. A Sourse Book. Blomington: Central for Innovation on Teaching The Handicapped.

Wenno, I. H. (2010). Pengembangan Model Modul IPA Berbasis Problem Solving
Method Berdasarkan Karakteristik Siswa dalam Pembelajaran di SMP/MTS. Cakrawala Pendidikan. No.2. 176-188. 